\title{
BROKEN SILHOUETTE OF A BUILDING: MYSTIQUE AND ETHICS
}

\author{
Vytautas Petrušonis \\ Dept of Fundamentals and Theory of Architecture, Vilnius Gediminas Technical University, Traku g. 1/26, \\ LT-01132Vilnius, Lithuania.E-mail:v.petrusonis@tkti.lt
}

Submitted 14 Nov 2006

\begin{abstract}
The paper aims at revealing the role of a broken silhouette of a building or a group of such buildings representing a hierarchical compositional type in programming ethically significant content in the recipient's consciousness. A city filled with a great number of buildings with a broken silhouette is distinguished by a dominating hierarchical compositional type. In fact, such a situation is unwelcome and even dangerous from the point of view of social programming, because it forms destructive attitudes in human consciousness. However, when placed in a contextually appropriate space, buildings with a dynamic outline will perform their "mission" of local compositional domination thus taking part in structuring a certain intrigue, forming ambiguity and together with organic elements expressing an idea of "collaboration".

Keywords: architectural composition, silhouette of architectural objects, organic compositional type, hierarchical compositional type, impact of architectural forms on human consciousness, mystique, ethics.
\end{abstract}

\section{Introduction}

The paper aims at revealing the role of a broken silhouette of a building or a group of such buildings in programming ethically significant content in the recipient's consciousness. The author has set himself the following tasks: 1) to analyse the phenomenon of strengthening (i e "usilenije", Alexandr Zholkovski's term [1]) in artistic texts as a means of rhetoric nature in ethical context; 2 ) to present ethically motivated features of the main compositional types (organic and hierarchical compositional types); 3) to present the structural features of a broken silhouette of a building (as representing the hierarchical compositional type) and to discuss the role of the broken silhouette phenomenon in the context of programming certain social models of behaviour in the recipient's consciousness.

The title of the paper demonstrates its paradoxical character. On the one hand, a very concrete, particular topic, i e that of a broken silhouette of a building, has been chosen, on the other hand, rather pathetically sounding words, such as mystique and ethics have been emphasized. How are these subjects related? A broken silhouette of a building (in other words, the outline of silhouette) is very active, $i \mathrm{e}$ it has a dynamic character when observed at a short distance. A building of such a silhouette requires much more attention on the part of the recipient. A thesis is declared that the phenomenon of a broken silhouette of a building is related with mys- tique through the phenomenon of programming certain social models of behaviour in the recipient's consciousness. Since people usually cannot directly experience how they are manipulated, in other words, their "eyes are closed" or their consciousness is affected in a mystical way: the etymology of the word mystique shows an association with closed eyes - in Gk. myein "to close, to shut", perhaps referring to lips (in secret) or to closed eyes (i e only initiates were allowed to see the sacred rites) [2].

\section{Analysis of the phenomenon of strengthening when applied to artistic texts in an ethical context}

Several remarks about the phenomenon of "strengthening" in texts in the context of programming social models in the recipient's consciousness. Miron Rash offers four main types of social relations among people: collaboration, revenge, domination, and isolation [3, p. 62]. Alexandr Zholkovski in his turn claims that the objects (as "targets") of a specific process, which he calls "strengthening" in artistic activity, are mostly life, death, love, visible world in general, success, etc [1, p 170]. These phenomena construct the "main vocabulary" of human life. The effect of "strengthening" is a crucial and constitutional condition of the impact of an artistic object. It is based on the "self-move- 
ment" of the fabula features. A. Zholkovski presents an example to show how, in a "silent" way, the fabula can be moved out: for instance, if you want to take from a hero his weapon, you can make use of etiquette rules - after an official meeting to invite him for the dinner before which he will have to hand in his weapon; then the last task of capturing warrior will be more than simple. Thus "strengthening" is a means and a result simultaneously. It is related with something that has a pre-reflective character, not expressed by words and motivated only by a situation.

Thus in the discussion of the value of artistic texts, the features of works of art, revealing what models of social communication they do pattern and what models of social stereotypes they do programme in human mind, should be taken into consideration. The patterns (or metaphors), which express sovereignty, domination, revenge, segregation, manipulation, etc, suggest what the world abounds in social situations of a polemic nature. Here the aspects of co-operation and harmonious behaviour are diminished. Therefore, critics should evaluate the balance of possible impact of images or metaphors in a certain context.

What is the role of architecture in this process? Since certain models of social relations can be presented in an artistic text both with the help of conceptual metaphors (generally called metaboles) and with "silent" structural elements "positionally" encoded in the space of the text serving as hidden metaphores having a mystic character. The latter principle is mostly suitable in architectural and urban compositions. Since the origin of architecture its forms have been playing an ideological role in modelling the world based on the ideas of social ("cosmic") order.

The mechanism of interaction or, in other words, configuration of the text, contextual information and attitude switches on when the perception of the text begins. Such a configuration is carried out (supported, fixed) by the metalanguage encoding the character of social relations. However, the formation of harmonistically emphasized attitudes is possible only if metalanguage enables parallel appealation both towards the experience and the state of mind of a person and towards the context of perception of the cultural text.

The analysis of the interaction of the text and its recipient will be reduced to an identification of the type of the metalanguage encoding a certain code of social relations in the text. After the identification step is completed, one can get a brief information about the capacity of the text to take part in the formation of harmonistically emphasized attitudes in the recipient"s mind. Taking into account this brief information the decision to change the text can be made. If, for instance, in the contemplation of the city square, the pressure of the patterns with polemic meanings prevails over the "twinkling" patterns, the programming of antihumanistic implications in human mind will start operating.

The main basis on which the conclusion about the relevance of metalanguage is founded is the criterion of the depth of the connotation found in the text. (Further remarks based on the concept of the depth of connotation have been stimulated by the recent ideas of the Russian cogitologist Victor Sergejev [4]). It may be revealed by studying a communicational situation and by taking into consideration the character and attitudes of the audience.

In the given case the relevant depth of connotation is supposed to encompass at least three levels. For its capacity to function metalogically (i e capacity to change the logic of the world structure in mind), the text (together with additional contextual information exposed to the recipient) must preserve at least three levels of connotation or semantization [4, p 126, 127].

Thus, further focus will be on the mentioned levels of semantization. In terms of social relations, the rules by themselves are senseless. They receive a sense only in certain actualized contexts. The set of rules represents the logic of actions. Such logic is not singular or exceptional and is capable of transforming itself regarding the circumstances and the type of the task. It possesses its own rules of a different level and nature which, for a lower level, serves as logic, and for a level that is still lower, serves as metalogic of actions [4, p 126].

While analysing the depth of semantization as one of the textual aspects, it is possible to identify the capacity of the text to implicate harmonistically marked states of mind, consideration and responsibility. Thus, a certain instrument for textological analysis, regarding the revelation of texts" capacity to form such states of mind, has been found. When the third level (i e metalogic of actions) is missing (in this case the metalogical operation is blocked down), it is not possible to give any meaning to the message in a wider context. The third level enables the location, the finding out of cultural concepts that could give a sense to the situation presented the message.

For the semantization that limits itself solely by the two levels, the context is not relevant. This type of semantization characterizes the text filled with absolute monologous assertions, statements and allusions that 
possess a unilateral and flat sense. Such texts do not stimulate the efforts of understanding the world, learning to accept other living creatures. They rather suggest the treatment of living beings as objects of subordination in terms of power, manipulation, and repression (in this context, such ecologically oriented concepts of Eric Fromm as necrophilic and biophilic ethics [5, p 31-36], Albert Schweitzer's concepts of ethic mystique and mystique of identity [6], and Alexandr Ljubischev's ideas of polemism and harmonism [7] would be noteworthy here. A. Schweitzer's ethic mystique can be explained in the following way: acting in unity with the world, mystique of identity means a situation when a subject acts with an attitude of distinctiveness towards himself [6]; the latter kind of mystique is correlated with the ideologies of totalitarian regimes.

\section{The role of the broken silhouette phenomenon in the context of programming adequate social models of behaviour in the recipient's consciousness}

Furthermore, what has been said about the limited semantization of the second level discussed above, in the case of arts, might be associated with the so-called hierarchical type of composition. The third level semantization (when the metalogic of the situation becomes understandable), which plays an essential role in the development of consideration and responsibility, respectively might be associated with the organic type of composition (the understanding of compositional types is based on the concepts developed by Elena Kirichenko [8]).

Hierarchical compositions (obviously, not exclusively in the sphere of architecture) "strengthen" the importance of domination and dictate, while the organic ones encourage collaboration. Contradiction between these two types of composition is asymmetric. In a certain environment smaller texts of a hierarchical type can make a natural part of a larger organic text. This is so because a hierarchical text is actually monological, tending to impose domination. However, when placed in a contextually appropriate space, it will perform its "mission" - local compositional domination (thus taking part in structuring a certain intrigue, forming ambiguity), expressing together with organic elements an idea of "collaboration". Hierarchical architectural texts tend to dominate because of their structural regularity (symmetrical-pivotal qualities, emphasis on centrality and verticality, etc). These features give a dramatical character to an architectural object, thus forming paradoxical junctions of "organic" and "hierarchical" intexts (i e inner texts) that help the recipient by evoking his/her emotions to make some private discoveries of the meaning offered by the text. However, it shouldn't be allowed to hierarchical elements to form the core of composition unilaterally.

Having defined the type of building composition before its reconstruction (which is equal to defining the type of metalanguage) as well as the type of the building composition as it is seen in its perspective reconstruction drawings, it is possible to foresee what compositional type will dominate after its reconstruction.

From the socio-cultural point of view, it is very important to preserve the existing compositional type of an urban environment. In fact, changes from an organic to hierarchical type should be very discrete. It is crucial to evaluate the compositional type of an urban space that covers a larger 'taxonomical radius' of the territory. In case the type of the composition is altered, a change from $\mathrm{H}$ to $\mathrm{O}$ is more welcome than vice versa.

These discussed principles for testing a compositional type of a building might be applied in the architecture of any historical period and in any region. In a more general sense, the author has discussed the impact of manifestations of different compositional types on the recipient's consciousness in the other papers $[9,10]$.

A broken silhouette of a building represents a hierarchical compositional type. A city filled with a great number of buildings with a broken silhouette is distinguished by a dominating hierarchical compositional type. In fact, such a situation is unwelcome and even dangerous from the point of view of social programming.

Testing of the compositional type of an urban complex differs from testing of the compositional type of a single building, but the main principles (i e distinguishing of hierarchical and organic elements as well as their interplay) remain the same.

Taking into consideration what has been already discussed above, it becomes evident how architecture, including buildings and urban complexes, might be evaluated from the point of view of enlightenment towards positive attitudes - consideration and responsibility. Architecture of a particular type might contribute to the neutralization of destructive attitudes in human consciousness, to the claim and assertion of life as well as action oriented by the biophilic ethic to use the term suggested by E. Fromm. 
The understanding of importance to assure consideration and responsibility should be evident as any elementary textbook truth. Doubtless, cultural texts should cultivate interrelation between an individual and his/her society in an appropriate way. Their authors should use the model of social relations founded on rightful metalanguage.

Art and culture could serve as a proper means to promote both "life assertion" and "life negation". Obviously, architecture plays a significant role too, since it surrounds man during his whole life, from birth to death. It is very important to construct architectural objects that posit life. By its forms, architecture presents the models of social interaction embedding harmonious principles of interaction and communication in human consciousness.

\section{Conclusions}

1. The architecture of buildings and urban complexes as well as the artistic products of other fields of art might be evaluated from the point of view of orientation towards positive, i e harmoniously emphasized, attitudes of consideration and responsibility.

2. Contrary to a hierarchical compositional type, architecture of an organic compositional type may contribute to the neutralization of destructive attitudes in human consciousness.

3. A broken silhouette of a building represents a hierarchical compositional type. A city filled with a great number of buildings with a broken silhouette is distinguished by a dominating hierarchical compositional type. In fact, such a situation is unwelcome and even dangerous from the point of view of social programming.

4. However, placed in a contextually appropriate space, buildings with a dynamic outline will perform their "mission" of local compositional domination thus taking part in structuring a certain intrigue, forming ambiguity and together with organic elements expressing an idea of "collaboration".

\section{References}

1. ЖОЛКОВСКИЙ, А. К. Об усилении. В кн. Структурнотипологические исследования. Москва: Изд-во АН СССР, 1962, c. $167-171$.

2. Term mystery // Online Etymology Dictionary [http://www. etymonline.com] [visited on 20061001 ]

3. РАШ, М. Менеджмент: Библейский путь. Bielefield: Logos, 1991.

4. СЕРГЕЕВ, В. М. Искусственный интеллект как метод исследования сложных систем. В кн. Системные исследования. Ежегодник, 1984. Москва: Наука, 1984, с. 116-129.
5. ФРОММ, Э. Душа человека: Перевод. Москва: Республика, 1992.

6. ШВЕЙЦЕР, А. Мировоззрение индийских мыслителей. Мистика и этика. В кн. Восток - Запад. Исследования. Переводы. Публикации. Москва: Наука, 1988, с. 209-233.

7. ЛЮБИЩЕВ, А. А. Понятия системности и организменности. Труды по знаковым системам, IX. Тарту, 1977, c. $134-141$.

8. КИРИЧЕНКО, Е. И. Пространственно-временные характеристики в русской архитектуре середины и второй половины XIX в. В кн. Типология русского реализма второй половины ХІХ века. Москва: Наука, 1979, с. 286-351.

9. PETRUŠONIS, V. The place of architecture in the realms of imagination and responsibility. Американские исследования: Ежегодник, 2003, часть II / Под ред. Ю. В. Стулова. Минск: Пропилеи, 2004, с. 278-286.

10. PETRUŠONIS, V. Simetrinès kompozicijos hipersemantinis aspektas. Iš Tekstai ir kontekstai: kalbos judesys. Kaunas: VU leidykla, 2005, p. 551-568 (in Russian).

\section{LAUŽYTAS PASTATO SILUETAS: MISTIKA IR ETIKA}

\section{Petrušonis}

Santrauka. Atskleidžiama pastatų su laužytu siluetu, priklausančių hierarchiniam kompoziciniam tipui, reikšmè programuojant suvokejo sąmonèje etiškai reikšmingus socialinès elgsenos modelius. Pastatų ir urbanistinių kompleksų architektūra kaip ir kitų meno sričių kūriniai gali būti vertinama pagal tai, ar skatina pozityvių - harmoningų socialinès sąveikos stereotipų formavimą, ar destrukcines nuostatas. Priešingai negu hierarchinio kompozicinio tipo architektūra, organinè architektūra aktyviai dalyvauja neutralizuojant destrukcines nuostatas. Miestas, kuriame yra daug pastatų, stebimų iš nedidelio atstumo, pasižymi laužytu, dinamišku kontūru, reikalaujančiu išskirtinio suvokẻjo dèmesio, pasižymi hierarchinio kompozicinio tipo dominavimu. Tokia padetis nèra patenkinama ir net yra grésminga socialinės elgsenos nuostatų programavimo požiūriu. Tačiau deriniuose su organiniais kompoziciniais elementais tokie objektai atliks savo lokalinio dominavimo misiją kurdami kompozicinę intrigą, prisidèdami prie etiškai reikšmingos bendradarbiavimo idejjos išreiškimo.

Reikšminiai žodžiai: architektūrinè kompozicija, architektūrinio objekto siluetas, organinis kompozicinis tipas, hierarchinis kompozicinis tipas, architektūros poveikis žmogaus sąmonei, mistika, etika.

\section{VYTAUTAS PETRUŠONIS}

Dr, Assoc Prof, Dept of Fundamentals and Theory of Architecture, Vilnius Gediminas Technical University (VGTU), Traku g. 1/26, LT-01132 Vilnius, Lithuania.

E-mail:v.petrusonis@tkti.lt.

Doctor of the Humanities (architecture), VGTU, 2005. First degree in Architecture, Vilnius Civil Engineering Institute (VISI, now VGTU) 1976. Projects: author or co-author of 16 realizations of architectural design projects and 12 projects of territory planning. Publications: author of 13 research papers and 36 scientific and criticism articles. Membership: member of LAS (Lithuanian Union of Architects) and ICOMOS Lithuanian National Committee. Research interests: structural and typological features of architectural objects, metacritical analysis of arcitectural activity. 